\title{
Barreling Down the Road to Recession?
}

\author{
Kristie M. Engemann and Michael T. Owyang
}

$\mathrm{T}$ he steady rise in oil prices since 2002 has evoked concern about possible negative effects on the economy. ${ }^{1}$ Could current energy prices push the United States into recession? Many economists have studied this question-in particular, how oil shocks affect both economic growth and inflation.

When consumer demand shifts away from energy-intensive goods as a result of rising oil prices, output declines in the near term as industries' capital and labor adjust. Timothy Bresnahan and Valerie Ramey studied the effect of the oil shocks of the 1970s and early 1980s on the automobile industry. Specifically, they examined how changing demand from standard-sized vehicles to smaller, more fuel-efficient cars affected the economy. They found that capacity utilization - the ratio of total cars produced to potential cars produced without using overtime-fell from above 100 percent in 1973 to around 50 percent in 1975. Similarly, capacity utilization fell from 100 percent to around 40 percent in $1982 .^{2}$ Both instances followed sustained high levels of gasoline prices, which caused such a shift in consumer choices. Today's high gas prices may do the same. The National Automobile Dealers Association reported that year-to-date SUV sales were down 19 percent in July compared with the same time last year.

Steven Davis and John Haltiwanger examined the effect of oil price shocks on manufacturing employment between 1972 and 1988. They found that the sharp rise in oil prices in 1973-74 led to an 8 percent decline in employment after two years and total job reallocation (job destruction plus job creation) of 11 percent after four years. In the short term, job reallocation was higher in industries that may require more time to adjust labor and capital (e.g., apparel, rubber and plastics, furniture, primary metals, and transportation equipment). ${ }^{3}$

Steep increases in oil prices might also translate into inflation of prices for other goods by increasing the cost of production. Mark Hooker examined the effects that oil has on personal consumption expenditure inflation, excluding food and energy (core PCE inflation). $\mathrm{He}$ found that, before 1981, a doubling of the price of oil would lead to a 3-percentage-point increase in core PCE inflation. ${ }^{4}$ The stance of monetary policy, however, ultimately dictates long-run inflation. Since 1981, the Fed has adopted a more anti-inflationary stance of monetary policy, potentially lessening economic disruption from oil price changes. ${ }^{5}$ Indeed, Hooker found that, post-1981, oil price increases have had statistically no effect on core PCE inflation.

Finally, can we expect a recession to occur as a result of current oil prices? James Hamilton believes that oil shocks affect economic growth only when, as a result of the higher prices, consumers' spending behavior changes. ${ }^{6}$ As the accompanying chart shows, PCE growth has remained positive since the real price of oil began to rise. The negative PCE growth that accompanied the previous oil shocks has not yet occurred during the current run-up in oil prices. Thus, as of now, economic growth appears to be more resilient to the negative effects of rising oil prices than in the 1970s and early 1980s.

\footnotetext{
${ }^{1}$ During the first half of August, the spot price of West Texas Intermediate, Cushing, was around $\$ 75$ per barrel (Wall Street Journal).

2 "Segment Shifts and Capacity Utilization in the U.S. Automobile Industry." AEA Papers and Proceedings, May 1993, 83(2), pp. 213-18.

3 "Sectoral Job Creation and Destruction Responses to Oil Price Changes." Journal of Monetary Economics, December 2001, 48(3), pp. 465-512.

4 "Are Oil Shocks Inflationary? Asymmetric and Nonlinear Specifications versus Changes in Regime." Journal of Money, Credit, and Banking, May 2002, 34(2), pp. 540-61.

${ }^{5}$ Herrera, Ana Maria and Pesavento, Elena. "Oil Price Shocks, Systematic Monetary Policy, and the 'Great Moderation." Unpublished manuscript, June 2005.

6 "Oil and the Macroeconomy." Palgrave Dictionary of Economics, August 2005.
}

Personal Consumption Expenditures and Real Oil Price

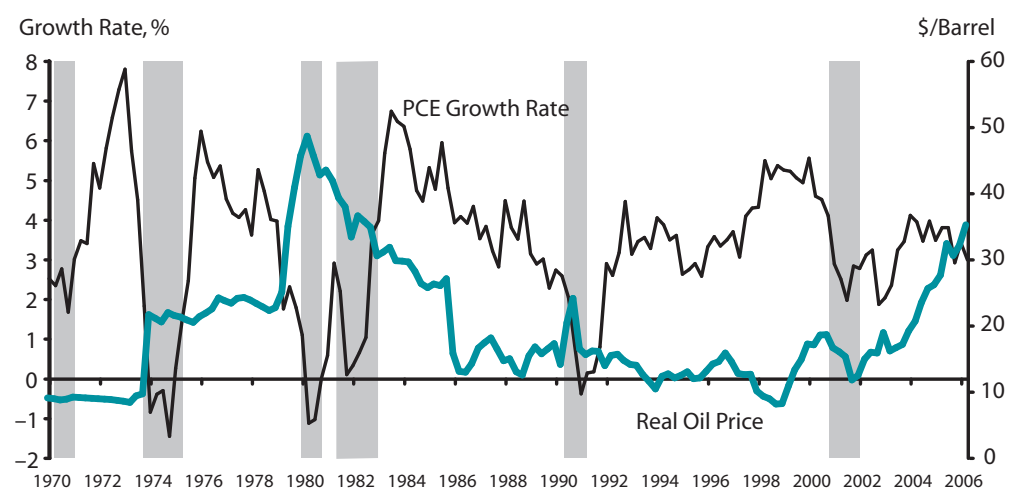

SOURCE: Recession dates (gray bars): National Bureau of Economic Research; personal consumption expenditures (SAAR, Billions of 2000\$): Bureau of Economic Analysis (growth rates are year-over-year percent change); Real oil price: Spot Oil Price of West Texas Intermediate Crude Oil (Wall Street Journal) divided by the seasonally adjusted consumer price index, all-items (Bureau of Labor Statistics) and multiplied by 100. 